\title{
COPD AND OCCUPATION: A RETROSPECTIVE COHORT STUDY OF INDUSTRIAL WORKERS*
}

\author{
Nailya N. MAZITOVA ${ }^{1}$, Anatoly A. SAVELIEV², Zuhra M. BERHEEVA ${ }^{1}$, and Nail Kh. \\ AMIROV $^{1}$ \\ Department of Hygiene and Occupational Medicine, Kazan State Medical University', Department of Environmental \\ Systems Modelling, Kazan Federal University², Kazan, Russian Federation
}

Received in December 2011

CrossChecked in February 2012

Accepted in July 2012

\begin{abstract}
The aim of this paper was to ascertain chronic obstructive pulmonary disease (COPD) prevalence among industrial workers in the Russian Federation and determine relative contribution of smoking and occupational factors to COPD.

We recruited 1,375 workers aged 30 or over. Six hundred and twenty-four of them were occupationally exposed to vapours, gases, dust, and fumes (VGDF). Physical examination and baseline spirometry were performed for all the participants of the study. Those with airflow limitation of $\mathrm{FEV}_{1} / \mathrm{FVC}<0.70$ were considered having COPD and those with presence of cough and sputum production for at least three months in each of two consecutive years were considered having chronic bronchitis (CB), with no overlapping between these 2 groups. Data on occupational history and VGDF levels in the working area were collected from all participants. In total, 105 cases of COPD and 170 cases of CB were diagnosed in the cohort of examined workers. Occupational exposure to VGDF was twice as often present among COPD patients than among both patients with $\mathrm{CB}$ and the control group of healthy workers $(\mathrm{p}<0.05)$. More than $40 \%$ of COPD patients were occupationally exposed to VGDF above the value of 3.0 of the occupational exposure limit (OEL) and more than $20 \%$ to 6.0 OEL and higher. Overall odds ratio for COPD development due to occupational VGDF exposure was $5.9(95 \% \mathrm{CI}=3.6$ to $9.8, \mathrm{p}=0.0001)$. Both smoking and VGDF seem to be important for the development of COPD. Analysis of the combined effect of tobacco smoking and occupational noxious particles and gases on COPD development has shown the following order of risk factors based on the strength of their influence: VGDF levels, smoking index, age, and heating microclimate. There is a statistically significant level of relationship and "dose-effect" dependence between occupational exposures to VGDF and the development of COPD. The effect of VGDF composition on the probability of COPD development was not found in the study. Results of this study were used to substantiate the inclusion of COPD into the National List of Occupational Diseases of the Russian Federation.
\end{abstract}

KEY WORDS: chronic obstructive pulmonary disease, occupational exposure, risk assessment, silica dust, smoking

Chronic obstructive pulmonary disease (COPD) is an increasing cause of chronic morbidity and mortality around the world (1). This disease, which

\footnotetext{
* Partly presented at the $5^{\text {th }}$ Croatian Congress on Occupational Health with International Participation "Health, Work, and Community", Hvar, Croatia, 28 September to 2 October 2011
}

has already affected 44 million people in Europe and is deemed the $4^{\text {th }}$ leading cause of death worldwide, is likely to become the $3^{\text {rd }}$ such cause by 2030 according to the predictions of the World Health Organization (3). Thus, the prognosis of CJ Murray 
and AD Lopez about the global burden of COPD, made in 1996 (2), has come true.

The major cause of COPD is smoking. However, tobacco smoking is not the only cause of COPD. According to the last updates of the Global Initiative for Chronic Obstructive Lung Disease (GOLD), occupational exposure is one of the two most important risk factors for COPD (4).

It is well known that tobacco smoke and occupational exposures exert a synergistic effect and increase each other's influence (5). However, relative impacts of each of these factors are poorly understood. Therefore differentiation between the two risk factors' individual effects may be important for planning strategies for the prevention and treatment of COPD.

Strong evidence implicates occupational exposures as one of the causes of COPD (6). A significant part of the literature accumulated over the past two decades demonstrated the relationship between vapour, gases, dust, and fumes (VGDF) and the development of COPD (7-13). However its importance remains underappreciated, especially in the Russian Federation. This applies particularly to the combined effect of occupational exposure and smoking. Since COPD develops predominantly during the working age, a comprehensive analysis of this joint effect seems to be important.

The aims of the present study were to ascertain the prevalence of COPD among industrial workers in the Russian Federation, to establish the relative contributions of smoking and occupational factors, and to investigate the accuracy of the following hypotheses: (1) COPD can be caused by VGDF only, irrespective of smoking; (2) there is a "dose - effect" dependence between VGDF and COPD development; and (3) the influence of smoking and VGDF on COPD development is similar.

Results of this study were used to corroborate the inclusion of COPD into the National List of Occupational Diseases of the Russian Federation.

\section{METHODS}

\section{Study design}

The retrospective cohort study was chosen due to its capability to study the outcomes after the exposure; the ability to yield true incidence rates, values of relative risks, and other measures of association.

\section{Study population}

One thousand three hundred and seventy-five workers, 879 men and 496 women, aged 30 to 60 years, were selected randomly for this study during periodical medical examinations of industrial workers, residents of three largest cities of the Republic of Tatarstan between June 2005 and December 2008 (Figure 1). The data were collected from workers of five enterprises - two foundry plants, one aircraft plant, and two oil extracting enterprises. Eligible participants were those who met the following inclusion criteria: (1) voluntary informed consent, (2) working for an industrial enterprise for at least five years. Exclusion criteria were: (1) refusal to participate in the study, (2) any other respiratory disease except COPD or chronic bronchitis (CB). Six hundred and twenty-four of included subjects were occupationally exposed to VGDF: 327 of these were exposed to silica dust, 244 to nonfibrogenic dusts, and 53 to nonfibrogenic dusts with vapours of irritants and sensitizers.

After medical examination, 22 workers were excluded from the study because four of them had been diagnosed with pneumoconiosis, and 18 with asthma. We compared three groups of workers: patients with $\mathrm{COPD}(\mathrm{N}=105)$, those with $\mathrm{CB}(\mathrm{N}=170)$, and a reference group of healthy workers with no signs of $\mathrm{COPD} / \mathrm{CB}(\mathrm{N}=1,100)$ (Figure 1).

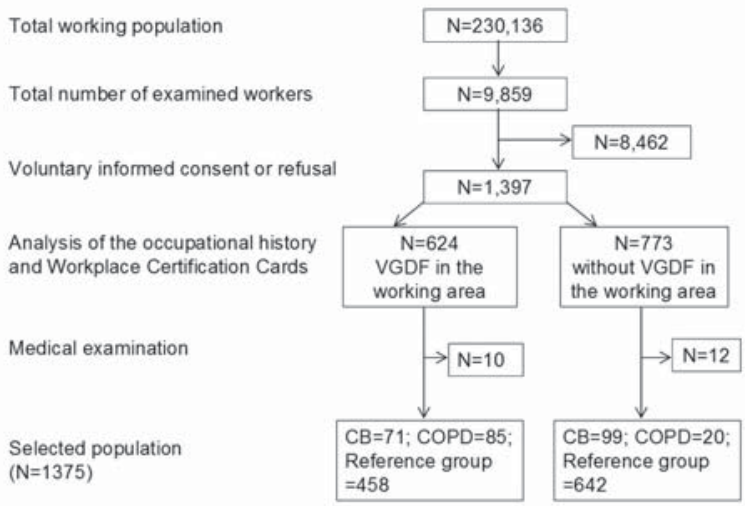

Figure 1 Selection of the study population

A hierarchical population sample was selected as follows: all subjects exposed to occupational hazards in the Republic of Tatarstan $(n=230,136)$; a total number of workers, aged 30 to 60 years, examined at the University Clinic of Occupational Medicine during 2005-2008 ( $n=9,859)$, workers who agreed to take part in the study $(n=1,397)$, subjects who had vapour, gases, dust and fumes $(V G D F)$ in their working area $(n=624)$, i.e. 10 excluded people (4 with pneumoconiosis, 6 with asthma), 71 with chronic bronchitis (CB), and 85 with chronic obstructive pulmonary disease (COPD); subjects without any $V G D F$ in their working area $(n=773)$, i.e. 12 were excluded due to asthma, 99 with $C B$, and 20 with $C O P D$. The total number of selected population was 1,375 people. 


\section{Definition of exposures}

Data on the smoking status and occupational exposures were collected from all study participants.

Subjects who had smoked a minimum of 100 cigarettes since they had started smoking were regarded as current smokers. Subjects who had smoked a minimum of 100 cigarettes in their lifetime but did not smoke at the time of the study were regarded as former smokers. Subjects who had never smoked or smoked less than 100 cigarettes were regarded as never smokers (14).

Workers who were regarded as both current and former smokers were included in the calculation of the smoking index. The average time elapsed since the former smokers quit smoking was 3.1 years.

Occupational exposure to VGDF was categorised into three groups: (1) silica dust, i.e. dust containing 10 or more percent of silica; (2) nonfibrogenic dusts; and (3) nonfibrogenic dust simultaneously with vapours of irritants and sensitizers. Occupational exposure limits (OEL) for each kind of VGDF were established by the Russian Federation regulations.

\section{Definition of outcomes}

We used common definitions for $\mathrm{COPD} / \mathrm{CB}$, used in the last GOLD revision (15). Therefore, we considered COPD as "a common preventable and treatable disease, characterised by persistent airflow limitation that is usually progressive and associated with an enhanced chronic inflammatory response in the airways and the lung to noxious particles or gases". We confirmed the presence of persistent airflow limitation using spirometry. Subjects with forced expiratory volume in 1 second and forced vital capacity ratio $\left(\mathrm{FEV}_{1} / \mathrm{FVC}\right)$ value of less than 0.7 were regarded as COPD patients. The stages of COPD were also determined according to GOLD criteria.

To evaluate chronic bronchitis, we used the GOLD (2011) diagnosis criteria: the presence of cough and sputum production for at least three months in each of two consecutive years (15).

Therefore, there was no overlapping between COPD and CB groups.

\section{Questionnaires}

We used the modified European Society for Coal and Steel (ECSC) questionnaire (16) for the preassessment of physical health status. We determined the degree of tobacco dependence using the modified Fagerstrom test (17). Both instruments were translated into Russian.

\section{Spirometric measurements}

Physical examination and baseline spirometry were performed for all the participants of the study. We used a portable computerised spirometer (Spirolab III, MIR, Italy). All spirometric measurements were performed by only one of the authors (MNN), respecting the American Thoracic Society (ATS)/European Respiratory Society (ERS) guidelines (18). We calculated the $\mathrm{FEV}_{1} / \mathrm{FVC}$ and the percentage of the predicted values for $\mathrm{FVC}\left(\mathrm{FVC} \%\right.$ predicted) and $\mathrm{FEV}_{1}$ ( $\mathrm{FEV}_{1} \%$ predicted) using published reference values for Europeans (19).

Study participants with value of FEV1/FVC of less than 0.7 were examined with post-bronchodilator test, which was performed according to the ATS / ERS guidelines (18) 15 minutes after the administration of 400 micrograms of salbutamol. The increase in $\mathrm{FEV}_{1}$ by more than $15 \%$ (or $200 \mathrm{~mL}$ ) from baseline was regarded as reversible obstruction.

\section{Occupational exposure assessment}

We evaluated occupational exposures in two ways. First, we assessed the workers' lifetime occupational exposures to VGDF directly by selfreports during the periodical medical examination. Subjects who answered affirmatively to at least one of the following two questions i.e.: "Have you ever worked for five years or more in any dusty job?" and/or "Have you ever been exposed (for five years or more) to gas or chemical fumes in your work?" were regarded as exposed to VGDF.

Second, we collected the data on current occupation, occupational history, and occupational exposure for all the study participants $(\mathrm{N}=1,375)$ : the employers provided us with all these information from the workplace certification cards, established by the Russian Federation regulations.

We combined different types of VGDF into three groups, as was described above, due to a large variety of occupational hazards in the foundry plants, where 15 to 36 various chemical substances could simultaneously be present in the working area. Occupational exposure to VGDF in the aircraft and oil extracting enterprises, i.e. nonfibrogenic dusts or organic solvent vapours in values of less than OEL, were present at a much smaller number of workplaces.

We took into account the influence of occupational exposures other than VGDF. We considered heating microclimate and excessive physical activity as two 
additional risk factors for occupational respiratory diseases because of their effects on the breathing rate. The information on the presence of overheating and excessive physical activity in the workplace were also drawn from workplace certification cards.

Occupational Exposure Limit values of VGDF were accepted according to the National hygienic standards.

\section{Data Analysis}

Analyses were conducted using the $\mathrm{R}$ statistical system (version 2.11.1) software (20). Prevalence of COPD and $\mathrm{CB}$ was estimated for the entire cohort by age, gender, education level, smoking status, and occupational exposures. The difference between variables was evaluated by Student's t-test for continuous data and chi-square test for categorical data. The main epidemiological criteria traditionally used as measures of association, i.e. odds ratio (OR), attributable risk (AR), and population attributable risk (PAR) were also calculated. The relationship between the influence of smoking and occupational factors for COPD development was analysed by CochranMantel-Haenszel test (CMH-test) of data stratification, with smoking being an additional affecting factor.

The logistic model of regression analysis was used for the same raw data to evaluate the combined effect of occupational exposures and smoking. Generalised additive model (GAM) (21) with binomial family was used to model the COPD probability; the model can include interactions between independent variables. The nonlinear dependence on smoking index was modeled using the smoothing term (22). "MGCV" package for $\mathrm{R}$ was used to fit the model.

To model the response with ordered values, Ordered Logistic Regression (23) was used. Model was fitted using the MASS R package to estimate

Table 1 General characteristics of the studied cohort

\begin{tabular}{|c|c|c|c|}
\hline & COPD $(n=105)$ & $\mathrm{CB}(\mathrm{n}=170)$ & $\begin{array}{l}\text { Reference group } \\
\qquad(\mathrm{n}=1100)\end{array}$ \\
\hline Age / year, mean $\pm \mathrm{SD}$ & $51.7 \pm 8.4 \dagger$ & $49.5 \pm 8,1$ & $47.5 \pm 9.9$ \\
\hline Women, n ( \%) & $3(2.9) \div$ & $46(26.7) \dagger$ & $447(40.6)$ \\
\hline \multicolumn{4}{|l|}{ Education level, n (\%): } \\
\hline Secondary & $99(94.3)^{*}$ & $152(89.4)$ & $930(84.5)$ \\
\hline Higher & $6(5.7) \dagger$ & $18(10.6)^{*}$ & $170(15.5)$ \\
\hline \multicolumn{4}{|l|}{ Level of income, $\mathrm{n}(\%)$ : } \\
\hline Low & $16(15.2) \dagger$ & $13(7.6)$ & $60(5.5)$ \\
\hline Middle & $83(79.0)$ & $103(60.6)^{*}$ & $910(82.7)$ \\
\hline High & $6(5.7)^{*}$ & $54(31.8)^{*}$ & $130(11.8)$ \\
\hline \multicolumn{4}{|l|}{ Smoking status, $\mathrm{n}(\%)$ : } \\
\hline Nonsmokers & $20(19.1) \dagger$ & $43(25.3) \dagger$ & $713(64.8)$ \\
\hline Smokers & $75(71.4) \dagger$ & $113(66.5) \dagger$ & $292(26.5)$ \\
\hline Former smokers & $10(9.5)$ & $14(8.2)$ & $95(8.6)$ \\
\hline \multicolumn{4}{|l|}{ Smoking index / pack-years, n (\%): } \\
\hline Less than 20 & $55(33.3) \dagger$ & $60(35.3) \dagger$ & $231(21.0)$ \\
\hline 20 or more & $50(47.6) \dagger$ & $67(39.4) *$ & $156(14.2)$ \\
\hline Occupational exposure to VGDF, n (\%) & $85(80.9) \dagger$ & $71(41.8)$ & $458(41.6)$ \\
\hline \multicolumn{4}{|l|}{ VGDF levels, $n(\%)$ : } \\
\hline Low $(<$ OEL to 3.0 OEL $)$ & $18(17.1) \dagger$ & $36(21.2)$ & $325(29.5)$ \\
\hline Medium (3.1 OEL to 6 OEL) & $46(43.8) \dagger$ & $35(20.6) \dagger$ & $106(9.6)$ \\
\hline High $(>6.0$ OEL $)$ & $21(20) \dagger$ & 0 & $27(2.5)$ \\
\hline \multicolumn{4}{|c|}{$\begin{array}{l}\text { The difference between variables was evaluated by Student's t-test for continuous data and chi-square test for cat } \\
\text { data. } \\
\text { Marked differences }(* p<0.01, \dagger-p<0.05, \neq-p<0.001) \text { between COPD and/or CB patients and control group. } \\
C O P D-\text { chronic obstructive pulmonary disease } \\
C B-\text { chronic bronchitis } \\
\text { VGOF - vapour, gases, dust and fumes } \\
\text { OEL - occupational exposure limit }\end{array}$} \\
\hline
\end{tabular}


confidence intervals. We built seven predictive models using the same initial data. As a dependent variable, relation to one of the following three groups of workers was taken into account: "healthy", "CB", and "COPD". The variables with discrete values were presented as the factors with fixed rates. Contributions of 14 factors in the model was estimated, i.e. sex, age, education, and income levels, VGDF levels in the working area, presence of other occupational factors, i.e. physical exertion, overheating, vibration, and noise. Besides, period of work, smoking status, smoking history, smoking index value, and the degree of nicotine dependence were estimated too. Contribution of each factor was evaluated separately. Significance of the factors was determined against the baseline, which was assumed to be the most important factor value in an importance order. The contribution of the baseline was considered as the zero value of the model to be defined.

The predictive capacity of models was evaluated by cross-validation and Receiver Operating Characteristic (ROC)-analysis. The repetitive crossvalidation (bootstrap) was used: data was split into teaching ( $80 \%$ of data) and validation ( $20 \%$ of data) subsets, model was fitted, and the predictions on the validation subset were compared with the true values. This procedure was repeated 100 times to estimate the histograms and confidence intervals; these results were used to select the best predictive model. ROC was estimated and plotted using the ROCR package (24).

\section{RESULTS}

In total, 105 cases of COPD and 170 cases of chronic bronchitis (CB) have been diagnosed in the cohort of workers examined (Table 1). Thus, prevalence of COPD was $7.5 \%$ for the entire cohort and $7.9 \%$ for people older than 40 ; prevalence of $\mathrm{CB}$ was $12.1 \%$ for the entire cohort and $13.4 \%$ for the people over 40. Distribution of COPD patients across stages according to the GOLD criteria was as follows: stage I - 69 people (65.7\%); stage II - 29 people $(27.6 \%)$, stage III - 7 people (6.7\%). Proportion of smokers was significantly lower in healthy workers than among COPD and CB patients $(\mathrm{p}<0.05)$. The highest proportion of smokers was found among patients with COPD. Occupational exposure to VGDF occurred twice more often among COPD patients than among both the $\mathrm{CB}$ patients and the control group of healthy workers $(p<0.05)$. More than $40 \%$ of COPD patients were occupationally exposed to VGDF on the level of 3.0 OEL and more. The 6.0 OEL and higher levels were found in more than $20 \%$ of COPD patients.

A strong link between exposure to VGDF at the workplace and COPD development was found (Table 2). Thus, the overall odds ratio for COPD development due to occupational VGDF exposure was 5.9 (95\% $\mathrm{CI}=3.6$ to $9.8 ; \mathrm{p}=0.0001$ ).

The values of odds ratios for different types of occupational noxious particles and gases among COPD patients were highest for silica dust $(\mathrm{OR}=6.2$; $95 \% \mathrm{CI}=3.6$ to $10.7 ; \mathrm{p}<0.0001)$. The same refers to other indicators of risk assessment, e.g. PAR \% values for COPD patients. The difference between PAR \% values for silica dust and other kinds of dust were not statistically significant $(56.7 \%$ and $49.8 \%, \mathrm{p}>0.05)$. The lowest value of PAR \% for COPD patients was found for occupational exposure to dust with vapours of irritants and sensitizers (18.3\%). The overall value of PAR \% obtained in our study was $65.3 \%$. This is more than three times higher than the value demonstrated in ATS statements $(2003,2010)(15,16)$ dedicated to occupational burden of lung diseases.

Another kind of dependence was found for $\mathrm{CB}$ patients. The overall odds ratio for $\mathrm{CB}$ development was statistically non-significant $(\mathrm{OR}=1.0 ; 95 \%$ $\mathrm{CI}=0.7$ to $1.4 ; \mathrm{p}=0.4$ ). However, the statistically significant value of odds ratio for $\mathrm{CB}$ development was obtained for VGDF levels above 3.0 OEL. The highest value of odds ratio was reached for $\mathrm{CB}$ patients who had occupational exposure to dust with vapours of irritants and sensitizers $(\mathrm{OR}=2.0 ; 95 \% \mathrm{CI}=1.0$ to $4.1 ; \mathrm{p}=0.07)$ but not for silica dust.

Occupational risk assessment calculated separately for nonsmoking and smoking workers showed that the odds ratios for occupational COPD were significantly higher for nonsmokers. For the smoking workers, smoking was a major risk factor for COPD development (Table 3). Thus, the odds ratio for occupational COPD for non-smokers was almost seven times higher than that of smokers and their attributable risk for occupational COPD was more than $95 \%$ compared to $65 \%$ for smokers. Total risk of COPD development for smoking workers due to the influence of both major risk factors for COPD, i.e. smoking and VGDF, was also calculated. As Table 3 shows, the overall value was about four times higher than the risk for nonsmoking workers. It is rather interesting that the risk 
of COPD from occupational VGDF exposures established for non-smoking workers was comparable with that obtained for smokers who were not in contact with VGDF in the working area.

As regards the second hypothesis, there is a quite clear and statistically significant "dose - effect" dependence between the level of occupational exposures and COPD development (Table 2). The risk assessment for occupational COPD revealed a regular and statistically significant risk increase when working conditions deteriorated.
Cochran-Mantel-Haenszel test of data stratification with smoking as an additional affecting factor showed the relationship between the influence of smoking and occupational factors. Higher values of odds ratios of COPD development (see above) were obtained for non-smoking workers (Table 4). The difference caused by the smoking status was statistically significant for workers with occupational exposure to silica dust and both to dust and irritants ( $\mathrm{p}=0.032$ and 0.012 , respectively). No significant difference between smokers and nonsmokers was found for

Table 2 The risk of COPD/CB development from occupational exposures to VGDF, depending on their type and levels

\begin{tabular}{|c|c|c|c|c|}
\hline & OR (95\% CI) & p-level & $\mathrm{AR} / \%$ & $\mathrm{PAR} / \%$ \\
\hline \multicolumn{5}{|l|}{ COPD } \\
\hline Overall & $5.9(3.6$ to 9.8$)$ & 0.0001 & 80.7 & 65.3 \\
\hline Low levels of VGDF * & $1.7(0.9$ to 3.4$)$ & 0.07 & 42.4 & 20.1 \\
\hline Medium levels of VGDF $†$ & $13.9(7.9$ to 24.5$)$ & $<0.0001$ & 90.0 & 62.7 \\
\hline High levels of VGDF $\$$ & $24.9(12.1$ to 51.5$)$ & $<0.0001$ & 93.1 & 47.7 \\
\hline Silica dust, i.e. dust containing $10 \%$ or $>10 \%$ silica & $6.2(3.6$ to 10.7$)$ & $<0.0001$ & 81.3 & 56.7 \\
\hline Nonfibrogenic dusts & $5.7(3.2$ to 10.2$)$ & $<0.0001$ & 80.0 & 49.8 \\
\hline $\begin{array}{l}\text { Nonfibrogenic dust simultaneously with vapours of } \\
\text { irritants and sensitizers }\end{array}$ & $5.5(2.1$ to 14.6$)$ & 0.002 & 79.3 & 18.3 \\
\hline \multicolumn{5}{|l|}{$\mathrm{CB}$} \\
\hline Contact with VGDF, including: & $1.0(0.7$ to 1.4$)$ & 0.4 & 0.45 & 0.19 \\
\hline Low levels of VGDF * & $0.7(0.5$ to 1.1$)$ & 0.1 & $<0$ & $<0$ \\
\hline Medium levels of VGDF $†$ & $2.1(1.4$ to 3.3$)$ & 0.0005 & 45.4 & 11.4 \\
\hline High levels of VGDF + & No data & & & \\
\hline Silica dust, i.e. dust containing $10 \%$ or $>10 \%$ silica & $1.0(0.7$ to 1.5$)$ & 0.8 & 25 & 0.34 \\
\hline Nonfibrogenic dusts & $0.8(0.5$ to 1.3$)$ & 0.4 & $<0$ & $<0$ \\
\hline $\begin{array}{l}\text { Nonfibrogenic dust simultaneously with vapours of } \\
\text { irritants and sensitizers }\end{array}$ & $2.0(1.0$ to 4.1$)$ & 0.07 & 48.3 & 11.6 \\
\hline
\end{tabular}

Levels of VGDF in the working area: *<OEL to 3.0 OEL; $†$ from 3.1 OEL to 6 OEL, $\neq>6.0$ OEL.

$C O P D$ - chronic obstructive pulmonary disease

$C B$ - chronic bronchitis

$V G D F$ - vapour, gases, dust and fumes

OEL - occupational exposure limit

Table 3 The risk values of chronic obstructive pulmonary disease (COPD) development among dusty trade workers and smokers not having any occupational exposures

\begin{tabular}{lcccc}
\hline & OR (95 \% CI) & p-level & AR/ \% & PAR / \% \\
\hline Nonsmoking workers in dusty trades & $22.2(4.9$ to 100.5$)$ & $<0.0001$ & 95.1 & 81.5 \\
\hline $\begin{array}{l}\text { Smoking workers in dusty trades (risk values due to } \\
\text { occupational exposures only) }\end{array}$ & $3.4(1.8$ to 6.5) & 0.0001 & 65.3 & 42.5 \\
\hline $\begin{array}{l}\text { Smoking workers in dusty trades (overall risk from } \\
\text { occupational and non-occupational exposures) }\end{array}$ & $82.7(19.9$ to 342.3) & $<0.0001$ & 98.3 & 95.2 \\
\hline $\begin{array}{l}\text { Smokers not having any VGDF in the working area (risk } \\
\text { value from smoking) }\end{array}$ & $34.7(7.9$ to 151.5) & $<0.0001$ & 96.7 & 87.0 \\
\hline
\end{tabular}

$O R$ - odds ratio

CI- confidence internal

AR - attributable risk

PAR - population attributable risk

$V G D F$ - vapour, gases, dust and fumes 
the workers who were occupationally exposed to other kinds of dust different from silica.

The logistic regression model investigated the combined effect of smoking and occupational exposures on COPD development using the same raw data. As shown in Table 5, the following factors specified in order of their significance were important for COPD: VGDF composition $\left(\chi^{2}=64.4 ; \mathrm{p}<0.0001\right)$, VGDF level $\left(\chi^{2}=63.3 ; \mathrm{p}<0.0001\right)$, smoking index $\left(\chi^{2}=43.2 ; \mathrm{p}<0.0001\right)$, age $\left(\chi^{2}=5.7 ; \mathrm{p}=0.01\right)$, and heating microclimate in the workplace $\left(\chi^{2}=5.2 ; \mathrm{p}=0.02\right)$. The contribution of all factors to the model was linear except for the smoking index.

Visual analysis of the curve of the influence of smoking index in the model of occupational COPD showed that its nonlinear dependence could be described by two linear curves: the effect of smoking index on the development of COPD in the model increased almost linearly from 0 to about 20 packyears, and then it remained practically unchanged (Figure 2). For this reason, a new variable was introduced in the model with values of smoking index

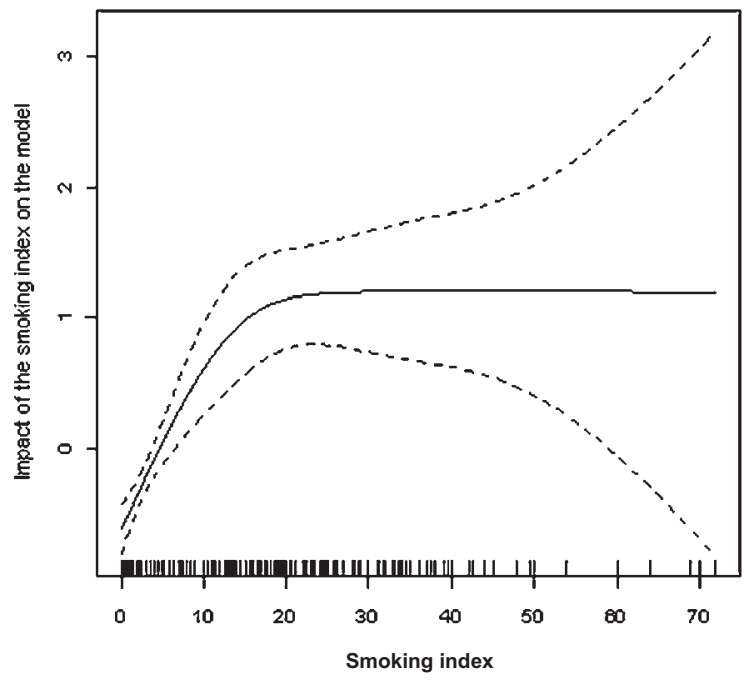

Figure 2 Effect of smoking index on the probability of chronic obstructive pulmonary disease (COPD) development

limited to the level of 20 pack-years. Assuming linear contribution of the smoking index in the model, the VGDF composition becomes insignificant for COPD development because of the counterbalancing effect of the smoking index and VGDF levels. In addition, the statistically significant interaction between two main predictors of occupational COPD (smoking index and VGDF levels) was found.

Analysis of the values of linear predictors in this model showed that the effect of smoking on COPD development in the cohort of workers studied ranged from $5 \%$ to $40 \%$ depending on other risk factors. The contribution of VGDF to COPD likelihood increased monotonously with the worsening of working conditions, with no changing in the likelihood of the COPD development, and was found statistically absolutely significant $(\mathrm{p}<0.0001)$. The VGDF impact was within $3 \%$ to $5.2 \%$ at low VGDF levels $(<3.0$ OEL), $33 \%$ at middle levels (from 3.0 OEL to 6.0 OEL), and reached $44 \%$ at high levels ( $>6.0 \mathrm{OEL})$.

Therefore, the degrees of smoking and VGDF influence on COPD development are probably rather similar. This suggestion was verified using seven predictive models with the same initial data. Ten from 14 studied occupational and non-occupational factors proved to be statistically significant in the models, i.e. age, gender, VGDF levels, type of VGDF, levels of irritants, physical stress, heating microclimate, smoking status, smoking index, and period of smoking. VGDF levels and the smoking index demonstrated maximal influence on $\mathrm{CB} /$ COPD probability. Age, gender, and levels of irritants exerted minimal but statistically significant influence.

Overall, average results of cross-validation showed high levels of reliability of predictiveness of the models on new data. The best results of crossvalidation and ROC-analysis were obtained for two models, i.e. three-level generalised linear model (GLM) "(0) healthy workers \& CB, (1) COPD", and two-level GLM-model "(0) healthy workers, (1) COPD” (Figures 3, 4).

\section{DISCUSSION}

Prevalence of COPD and CB obtained in this study correspond to average data in the Russian Federation and internationally (4).

High values for odds ratios of COPD development obtained in our study indicate a high level of the occupationally determined risk for COPD. This allows discussing possible inclusion of the disease in the National List of Occupational Diseases. However, a well-known statement "Chronic bronchitis is the biggest single cause of sickness absence" (25) also explains the impressive difference between COPD and $\mathrm{CB}$ odds ratio values shown in this study. A substantial difference between OR, AR, and PAR \% values for COPD and CB call for the possible update of the classification of occupational airways diseases. 

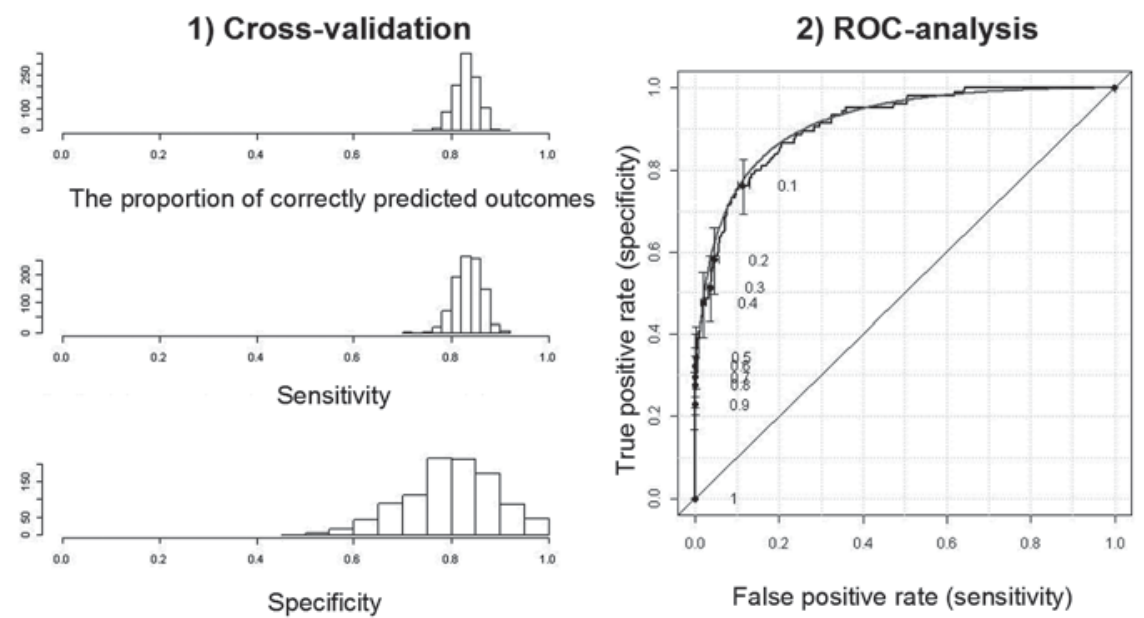

Figure 3 Results of verification for the model " 0 - healthy workers and chronic bronchitis (CB) patients; 1 - chronic obstructive pulmonary disease (COPD) patients" ROC-analysis $=$ Receiver Operating Characteristic Analysis
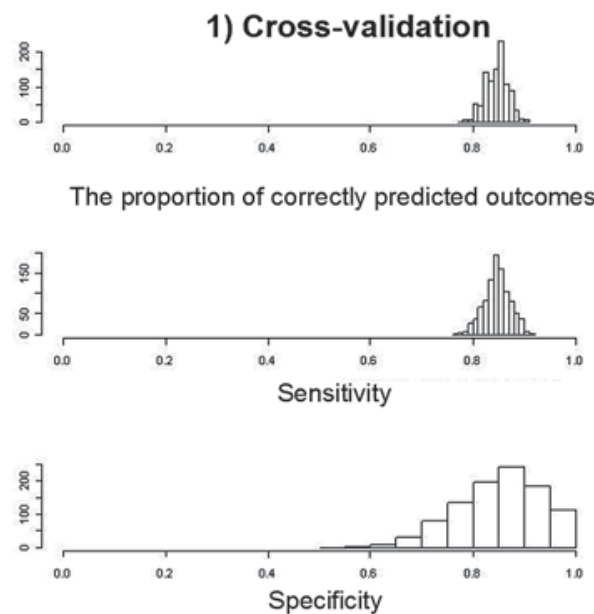

2) ROC-analysis

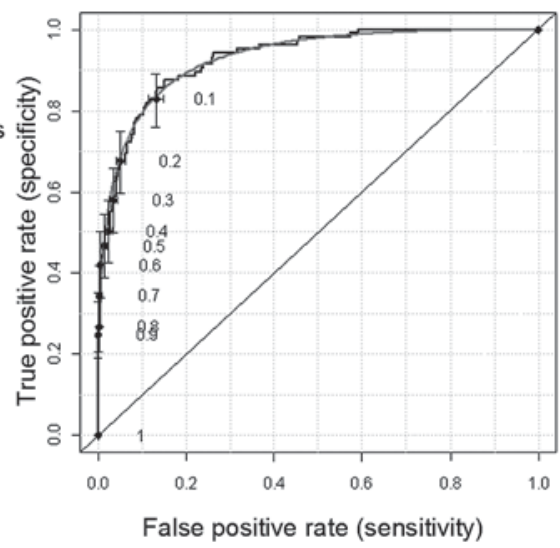

Figure 4 Results of verification for the model "0 - healthy workers; 1- COPD patients" ROC-analysis $=$ Receiver Operating Characteristic Analysis

"Dose - effect" dependence between VGDF levels and COPD development (see Table 2), is another argument in favour of the possibility of COPD being developed due to VGDF only.

The odds ratio and other risk assessment criteria of COPD development for the silica dust exposed workers obtained here confirm again the importance of this risk factor (26). Insignificant difference between PAR \% values for silica dust and other kinds of dust indicates the importance of all kinds of occupational noxious particles for COPD development. Further research is required for the comparative impact of occupational factors to be evaluated.

As Table 2 shows, the values of PAR \% for workers exposed to low VGDF levels $(<3.0$ OEL) are very close to the results obtained in other studies of occupational COPD published earlier (27-29).
However, our study showed that the values of risk assessment were much higher for the workers exposed to higher VGDF levels. This might result from much poorer working conditions at the foundry plants in the Russian Federation, and relatively high VGDF levels in the working area of dusty trade workers included in the cohort studied. Therefore, the effect of VGDF should be evaluated according to the levels in the working area. This may be useful for future strategies of occupational risk management.

We have also found that non-smoking dusty trade workers run the risk of developing occupational COPD six times more than smoking dusty trade workers (see Table 3). This is similar to the results described earlier by Becklake (30) in her classic epidemiological study of the prevalence of occupational COPD. 
Table 4 The relationship between smoking and occupational factors in the development of chronic obstructive pulmonary disease (COPD)

\begin{tabular}{|c|c|c|c|c|}
\hline & \multicolumn{2}{|c|}{ OR (95 \% CI) } & \multirow{2}{*}{$\begin{array}{l}\text { CMH-test for } \\
\text { homogeneity, } \chi^{2}\end{array}$} & \multirow[b]{2}{*}{ p-level } \\
\hline & $\begin{array}{l}\text { Smoking } \\
\text { workers }\end{array}$ & $\begin{array}{c}\text { Nonsmoking } \\
\text { workers }\end{array}$ & & \\
\hline $\begin{array}{l}\text { Silica dust, i.e. dust containing } 10 \% \text { or }>10 \% \\
\text { silica }\end{array}$ & $\begin{array}{c}3.5 \\
(1.8 \text { to } 6.8)\end{array}$ & $\begin{array}{c}20.6 \\
(4.5 \text { to } 190.7)\end{array}$ & 4.61 & 0.033 \\
\hline Nonfibrogenic dusts & $\begin{array}{c}3.7 \\
(1.9 \text { to } 7.4)\end{array}$ & $\begin{array}{c}9.76 \\
\text { (1.4 to } 109.4)\end{array}$ & 1.08 & 0.300 \\
\hline $\begin{array}{l}\text { Nonfibrogenic dust simultaneously with vapours } \\
\text { of irritants and sensitizers }\end{array}$ & $\begin{array}{c}1.75 \\
(0.4 \text { to } 5.8)\end{array}$ & $\begin{array}{c}32.1 \\
(1.0 \text { to } 7.0)\end{array}$ & 6.28 & 0.013 \\
\hline
\end{tabular}

CMH-test $=$ Cochran-Mantel-Haenszel test

Table 5 The significance of risk factors to the development of chronic obstructive pulmonary disease (COPD) in a model of multiple logistic regression

\begin{tabular}{|c|c|c|c|c|}
\hline & With init & of smoking & With tr & $\begin{array}{l}\text { values of } \\
\text { dex }\end{array}$ \\
\hline & $\chi^{2}$ & $\mathbf{p}$ & $\chi^{2}$ & $\mathbf{p}$ \\
\hline Type of VGDF & 64.5 & $<0.0001$ & 0.9 & 0.6288 \\
\hline Level of VGDF & 63.3 & $<0.0001$ & 70.8 & $<0.0001$ \\
\hline Smoking index & 43.2 & $<0.0001$ & 43.5 & $<0.0001$ \\
\hline Age & 5.7 & $<0.0200$ & 5.9 & $<0.0140$ \\
\hline Heating microclimate & 5.2 & $<0.0230$ & 5.3 & $<0.0220$ \\
\hline
\end{tabular}

$V G D F$ - vapour, gases, dust and fumes

Data stratification performed by Cochran-MantelHaenszel test in our study showed again that nonsmoking workers have higher probability of developing the disease (see Table 4) with the isolated impact of occupational risk factors for COPD. The difference due to the smoking status in the cohort studied was statistically significant for both silica dust and for dusts and irritants present simultaneously in the working area ( $p=0.032$ and 0.012 , respectively). For other types of dust, except quartz, no significant difference was found between smokers and nonsmokers. This points to a more important role of silica dust and irritants in the development of COPD.

It should be pointed out that smoking workers are influenced by both major risk factors for COPD. For non-smoking dusty trade workers, the risk of COPD is caused only by VGDF. Therefore, we evaluated the overall risk for COPD development from occupational and non-occupational exposures and the result was that the overall risk for workers influenced by both major risk factors for COPD is about four times higher than that caused by VGDF only. The studies performed by Meer et al. (31) and Blanc et al. (32) showed similar results. This makes us think about the necessity of planning preventive strategies and developing smoking cessation programs for dusty trade workers.

Similar results were obtained in our study for COPD risk due to occupational VGDF exposures for non-smoking dusty trade workers and for smokers who did not have contact with VGDF in the working area. This confirms again the well-known thesis of the two main risk factors for COPD, i.e., smoking and noxious particles and gases, whose influence seems comparable.

Analysis of the combined effect of tobacco smoking and occupational noxious particles and gases for COPD development showed the following order of risk factors based on the strength of their influence: VGDF levels, smoking index, age, and heating microclimate. The values of impact of VGDF and smoking for COPD development are similar in the regression model used.

The results of cross-validation and ROC-analysis revealed the highest level of sensitivity and specificity for two models made. The two-level GLM-model "(0) healthy workers; (1) COPD" showed the best result of cross-validation. However, the realisation of the method assuming the artificial exclusion of $\mathrm{CB}$ patients from the database does not allow the model for prediction to be applied. 
Nevertheless, high analytical capacity of this model provides the application of its predictors as the assessment criteria for medical examination of workers. The three-level GLM-model "(0) healthy workers \& CB; (1) COPD" showed the second best results of cross-validation. All of the results of cross-validation and ROC-analysis fully support the conclusion made.

\section{CONCLUSIONS}

The differentiation between the various effects of inhaled noxious particles and gases seems to be complex. But this task is particularly challenging for the Russian Federation because of a high number of smokers in the country. Therefore, a comprehensive assessment of contribution of the two leading risk factors for COPD is of special interest for occupational medicine. Future investigations of occupational COPD seem to be important for developing prevention strategies.

\section{REFERENCES}

1. World Health Organization (WHO). The World Health Report 2008 - primary Health Care (Now More Than Ever). Geneva: WHO; 2008 [displayed 25 November 2011]. Available at http://www.who.int/whr/2008/en/index.html

2. Murray CJ, Lopez AD. The Global Burden of Disease: A Comprehensive Assessment of Mortality and Disability from Diseases, Injuries and Risk Factors in 1990 and Projected to 2020. Vol I. Cambridge (MA): Harvard University Press; 1996.

3. Decramer M, Sibille Y. European Respiratory Roadmap. Recommendations for the future of respiratory medicine. Lausanne: ERS; 2011.

4. Global Initiative for Chronic Obstructive Lung Disease. Global Strategy for the Diagnosis, Management, and Prevention of Chronic Obstructive Pulmonary Disease (Updated December 2010): Medical Communication Recourses, Ink. 2010. [displayed 22 November 2011]. Available at http://www.goldcopd.com

5. Ameille J, Dalphin JC, Descatha A, Pairon JC. La bronchopneumopathie chronique obstructive professionnelle: une maladie méconnue [Occupational chronic obstructive pulmonary disease : a poorly understood disease, in French]. Rev Mal Respir 2006;23(4 Suppl):13S119-30.

6. Eisner MD, Anthonisen N, Coultas D, Kuenzli N, PerezPadilla R, Postma D, Romieu I, Silverman EK, Balmes JR; Environmental and Occupational Health Assembly Committee on Nonsmoking COPD. An official American Thoracic Society public policy statement: Novel risk factors and the global burden of chronic obstructive pulmonary disease. Am J Respir Crit Care Med 2010;182:693-718.
7. Blanc PD, Torén K. Occupation in chronic obstructive pulmonary disease and chronic bronchitis: an update. Int J Tuberc Lung Dis 2007;11:251-7.

8. Christiani DC. Occupation and COPD. Occup Environ Med 2005;62:215.

9. Boschetto P, Quintavalle S, Miotto D, Lo Cascio N, Zeni E, Mapp CE. Chronic obstructive pulmonary disease (COPD) and occupational exposures. J Occup Med Toxicol 2006;1:11

10. Melville AM, Pless-Mulloli T, Afolabi OA, Stenton SC. COPD prevalence and its association with occupational exposures in a general population. Eur Respir J 2010;36:48893.

11. Harber P, Tashkin DP, Simmons M, Crawford L, Hnizdo E, Connett J; Lung Health Study Group. Effect of occupational exposures on decline of lung function in early chronic obstructive pulmonary disease. Am J Respir Crit Care Med 2007;176:994-1000.

12. Fishwick D, Barber CM, Darby AC. Review series: Occupational and environmental lung disease: Chronic obstructive pulmonary disease and the workplace. Chronic Respir Dis 2010;7:113-22.

13. Centers for Disease Control and Prevention (CDC). Cigarette smoking among adults - United States, 1992, and changes in the definition of current cigarette smoking. MMWR Morb Mortal Wkly Rep 1994;43(19):342-6.

14. Global Initiative for Chronic Obstructive Lung Disease (GOLD). Global Strategy for the Diagnosis, Management and Prevention of COPD, 2011. [displayed 22 November 2011]. Available at http://www.goldcopd.org/

15. Minette A. Questionnaire of the European Community for Coal and Steel (ECSC) on respiratory symptoms: 1987 updating of the 1962 and 1967 questionnaires for studying chronic bronchitis and emphysema. Eur Respir J 1989;2:16577.

16. Heatherton TF, Kozlowski LT, Frecker RC, Fagerström KO. The Fagerström Test for Nicotine Dependence: a revision of the Fagerström Tolerance Questionnaire. Br J Addict 1991;86:1119-27.

17. Miller MR, Hankinson J, Brusasco V, Burgos F, Casaburi R, Coates A, Crapo R, Enright P, van der Grinten CP, Gustafsson P, Jensen R, Johnson DC, MacIntyre N, McKay R, Navajas D, Pedersen OF, Pellegrino R, Viegi G, Wanger J; ATS/ERS Task Force. Standardization of spirometry. Eur Resp J 2005;26:319-38.

18. Quanjer PH, Tammeling GJ, Cotes JE, Pedersen OF, Peslin R, Yernault JC. Lung volumes and forced ventilatory flows. Report Working Party Standardization of Lung Function Tests, European Community for Steel and Coal. Official Statement of the European Respiratory Society. Eur Respir J 1993;6(Suppl 16):S5-40.

19. R Development Core Team. R: A language and environment for statistical computing. R Foundation for Statistical Computing, Vienna, Austria [displayed 22 November 2011]. Available at http://www.R-project.org

20. Wood SN. Fast stable restricted maximum likelihood and marginal likelihood estimation of semiparametric generalized linear models. J Roy Stat Soc B Stat Meth 2011;73:3-36.

21. Wood SN. Stable and efficient multiple smoothing parameter estimation for generalized additive models. J Am Stat Assoc 2004;99:673-86. 
22. Venables WN, Ripley BD. Modern Applied Statistics with S. Fourth Edition. New York (NY): Springer; 2002.

23. Sing T, Sander O, Beerenwinkel N, Lengauer T. ROCR: Visualizing the performance of scoring classifiers Bioinformatics 2005;21:3940-1.

24. Newhouse ML. The prevalence of occupational disease. Ann Occup Hyg 1976;19:285-92.

25. Rushton L. Chronic obstructive pulmonary disease and occupational exposure to silica. Rev Environ Health 2007;22:255-72.

26. Hnizdo E, Vallyathan V. Chronic obstructive pulmonary disease due to occupational exposure to silica dust: a review of epidemiological and pathological evidence. Occup Environ Med 2003;60:237-43.

27. Balmes J, Becklake M, Blanc P, Henneberger P, Kreiss K, Mapp C, Milton D, Schwartz D, Toren K, Viegi G;
Environmental and Occupational Health Assembly, American Thoracic Society. American Thoracic Society Statement: Occupational contribution to the burden of airway disease. Am J Respir Crit Care Med 2003;167:787-97.

28. Becklake MR. Occupational exposures: evidence for a causal association with chronic obstructive pulmonary disease. Am Rev Respir Dis 1989;140(3 Pt 2):S85-91.

29. de Meer G, Kerkhof M, Kromhout H, Schouten JP, Heederik D. Interaction of atopy and smoking on respiratory effects of occupational dust exposure: a general population-based study. Environ Health 2004;3:6.

30. Blanc PD, Eisner MD, Earnest G, Trupin L, Balmes JR, Yelin EH, Gregorich SE, Katz PP. Further exploration of the links between occupational exposure and chronic obstructive pulmonary disease. J Occup Environ Med 2009;51:804-10. 


\section{Sažetak \\ KRONIČNA OPSTRUKTIVNA PLUĆNA BOLEST I RAD: RETROSPEKTIVA ISTRAŽIVANJA PROVEDENOG NA KOHORTI INDUSTRIJSKIH RADNIKA}

Cilj ovog rada bio je potvrditi prevalenciju kronične opstruktivne plućne bolesti (engl. chronic obstructive pulmonary disease, COPD) među industrijskim radnicima u Ruskoj Federaciji i utvrditi relativni doprinos pušenja i profesionalnih čimbenika razvoju COPD-a.

Odabrali smo 1.375 radnika u dobi od 30 godina i starijih. Šeststo dvadeset i četiri radnika bila su izložena parama, plinovima, prašini i dimovima (engl. vapours, gases, dust, and fumes - VGDF) na radu. Svi su radnici bili podvrgnuti fizičkom pregledu i temeljnoj spirometriji. Za radnike koji su imali smanjen protok zraka $\left(\mathrm{FEV}_{1} / \mathrm{FVC}<0,70\right)$ smatralo se da imaju COPD, a za one koji su imali kašalj i pojačan sputum barem 3 mjeseca tijekom dvije uzastopne godine smatralo se da boluju od kroničnog bronhitisa (CB). Između ove dvije skupine nije bilo preklapanja. Od svih su sudionika prikupljeni podaci o radnoj anamnezi i razinama izloženosti VGDF-u na radu. Profesionalna izloženost VGDF-u bila je dvostruko češce prisutna kod radnika s COPD-om nego kod radnika s CB-om i kod kontrolne skupine zdravih radnika ( $<0,05)$. Više od 40 \% bolesnika s COPD-om bilo je profesionalno izloženo VGDF-u iznad 3,0 OEL (engl. occupational exposure limit - granica profesionalne izloženosti), a više od 20 \% granici od 6,0 OEL i više. Ukupni omjer izgleda (engl. odds ratio - OR) za razvoj KOPB-a zbog izloženosti VGDF-u bio je 5,9 (95 \%-tni CI=3,6 do 9,8; p=0,0001). Čini se da su i pušenje i VGDF važni za razvoj COPD-a. Analiza sjedinjenog učinka pušenja i profesionalne izloženosti štetnim česticama i plinovima na razvoj COPD-a pokazala je ovakav redoslijed čimbenika rizika prema jačini njihova utjecaja: razine VGDF-a, indeks pušenja, dob i mikroklima grijanja. Postoji statistički značajna veza i ovisnost ,doza-učinak“ između profesionalne izloženosti VGDF-u i KOPB-a. Utjecaj sastava VGDF-a na vjerojatnost razvoja COPD-a nije utvrđen u istraživanju. Rezultati ovog rada potvrdili su potrebu uvrštavanja COPD-a u Nacionalni popis profesionalnih bolesti Ruske Federacije.

KLJUČNE RIJEČI: COPD, filtarska prašina, procjena rizika, profesionalna izloženost, pušenje

\section{CORRESPONDING AUTHOR:}

Nailya N. Mazitova

Butlerova str., 49

420012 Kazan, Russian Federation

E-mail: nailya.mazitova@gmail.com 